\title{
Revisiting the Case of Customary International Tax Law
}

\author{
Dirk Broekhuijsen \\ Assistant Professor, Leiden Law School, Leiden University, \\ Leiden, The Netherlands \\ d.m.broekhuijsen@law.leidenuniv.nl \\ Irma Mosquera Valderrama \\ Associate Professor, Leiden Law School, Leiden University, \\ Leiden, The Netherlands \\ i.j.mosquera.valderrama@law.leidenuniv.nl
}

\begin{abstract}
Customary international tax law has traditionally not received a lot of acclaim in international tax law literature. However, the infrastructure of international tax law is becoming increasingly multilateral. The recent adoption of the Multilateral Instrument and the creation of the Inclusive Framework, two initiatives related to the OECD/G2O Base Erosion and Profit Shifting Project, have accelerated the width of cooperation on international tax matters. For that reason, the authors (re)consider the existence of customary international law in the area of international tax law. They conclude that, perhaps contrary to the intuition of tax lawyers, the evidence in favour of customary international tax law is building up. The question whether customary law exists within the area of international taxation is therefore not misplaced.
\end{abstract}

\section{Keywords}

international tax law - customary international law - principal purpose test BEPS and aggressive tax planning - tax interpretation - Base Erosion and Profit Shifting - OECD - multilateral 
The field of international tax law is experiencing a surge in multilateral cooperation. In 2013, the Organization for Economic Cooperation and Development (OECD), with the political mandate of the G2o, introduced the Base Erosion and Profit Shifting (BEPS) Project to prevent aggressive tax planning by multinationals. ${ }^{1}$ In 2015, the OECD presented 15 Actions, four of which selected as minimum standards, to tackle BEPS (the BEPS action plan), ${ }^{2}$ and consented to by the BEPS 44 group (G2O and OECD (accession)) $)^{3}$ countries. ${ }^{4}$ As a result of this, the following multilateral initiatives can now be discerned in the field of international tax law by means of which rules addressing aggressive tax planning are implemented and monitored:

- Multilateral instrument. The BEPS actions for which amendments to bilateral tax treaties are needed, are implemented by means of the OECD "Multilateral Convention to Implement Tax Treaty Related Measures to Prevent Base Erosion and Profit Shifting" (commonly referred to as "multilateral instrument" or MLI). At the time of writing, more than 90 jurisdictions have signed the MLI (of which more than 30 jurisdictions have ratified and more are expected to ratify)..$^{5}$ The MLI entered into force as of 1 July $2018 .^{6}$

- BEPS Inclusive Framework. In June 2016, representatives of more than 80 countries gathered in Kyoto, Japan to push forward the BEPS Project by creating the BEPS Inclusive Framework. ${ }^{7}$ In this Framework, countries

1 See the OECD website: http://www.oecd.org/tax/beps/. Accessed on 20 December 2020.

2 OECD, "Action Plan on Base Erosion and Profit Shifting" (2013), http://www.oecd.org/ctp/ BEPSActionPlan.pdf.

3 The OECD accession countries at that time were: Colombia and Latvia. Since then, Latvia has become full member of the OECD and Colombia is in process of formalization of the OECD membership. See the OECD website: http://www.oecd.org/about/members andpartners/ and http://www.oecd.org/about/secretary-general/signing-ceremony-of-oecd -accession-agreement-with-colombia-and-lithuania-france-30-may-2018.htm. Accessed on 20 December 2020 .

4 See the oEcD website: http://www.oecd.org/tax/beps/beps-actions.htm. Accessed on 20 December 2020.

5 The countries that have signed the MLI are all (except one) members of the BEPS Inclusive Framework. Cyprus is the only country that is not a member of the BEPS Inclusive Framework. https://www.oecd.org/tax/treaties/beps-mli-signatories-and-parties.pdf. Accessed on 20 December 2020.

6 The MLI entered into force following the deposit of the $5^{\text {th country instrument of ratifica- }}$ tion. The first 5 countries were Slovenia, Austria, Isle of Man, Jersey and Poland.

7 Furthermore, in June 2017 more than 70 countries signed the OECD "Multilateral Convention to Implement Tax Treaty Related Measures to Prevent Base Erosion and Profit Shifting" 
committed to the implementation on equal footing of the BEPS 4 Minimum Standards which deal with harmful tax competition, tax treaty abuse, transfer pricing documentation and dispute resolution (BEPS Actions 5, 6, 13 and 14). At the time of writing (June 2020), 137 jurisdictions have committed to the implementation of the BEPS 4 Minimum Standards. ${ }^{8}$

With multilateral cooperation becoming more and more present in discussions, formation as well as the implementation of new rules of international tax law, and with increasingly wider forms of acceptance of "minimum" international tax law standards across the world (including non-OECD and non-G2O countries), it is time to (re)consider the existence of customary international tax law, which has traditionally not had much support in academic literature. ${ }^{9}$

An aspirant for customary international tax law comes in the form of one of the minimum standards against aggressive tax planning included in the BEPS Inclusive Framework and in the MLI: the aim to tackle tax treaty abuse and tax treaty shopping. It provides an important outcome of the BEPS Project, as one of its rules, the "principal purpose test" (РPT), has been widely if not universally accepted by more than 130 jurisdictions. ${ }^{10}$ Particularly considering the fact that dealing with aggressive tax planning is "new" to international tax law in the sense that it requires multilateral norms to deal with prisoner dilemmatype of situations, ${ }^{11}$ has the charm of customary international law increased in the area of international tax law?

(commonly referred to as "multilateral instrument" or MLI). The MLI modifies bilateral tax treaties with regard to some of the BEPS Actions including also 2 of the 4 Minimum Standards agreed upon within the BEPS Project (Actions 6 and 14).

8 See the OECD website: https://www.oecd.org/ctp/beps/inclusive-framework-on-beps -composition.pdf_Accessed on 20 December 2020.

$9 \quad$ See section 2.2.1 and 2.2.2.

10 See section 3 .

11 In a prisoners' dilemma, prisoners A and B are locked up for having committed a crime and are questioned separately by the public prosecutor. Each prisoner knows that if neither confesses, both will be put in prison for 30 days. If both A and B confess, however, they will each be sentenced to a year. If either confesses while the other refuses, the confessor will not be prosecuted at all, while the other is punished severely with a five-year sentence. Hence, on the basis of narrow self-interest, prisoner A knows that he should confess, whatever his partner, prisoner B, does. If B refuses to confess, A's confession will let him go free. If B confesses, A's own confession will at least save him from the severe five-year sentence. However, the walls between the two prison rooms prevent the prisoners from communicating, and there is only one game played. Therefore, both A and B's preferred course of action, if they are self-interested and rational individuals, is to confess. They hence receive prison sentences that they could have avoided. As many cooperative structures in international relations (including international taxation) resemble prisoners' dilemmas, it is helpful to analyse them with that idea in mind. See R. O. Keohane, After Hegemony: Cooperation and Discord in the World Political Economy (1984) pp. 85-110. 
Hence, the main question of this article is to see what evidence there is for customary international tax law. In order to answer this question, this article is structured as follows. Section 2 will first address the main elements of customary international law as developed by the International Court of Justice (ICJ) cases, ${ }^{12}$ the 2000 Statement by the International Law Association ("ILA") ${ }^{13}$ and the 2018 Report by the UN International Law Commission ("ILC"). ${ }^{14}$ Furthermore, this section also presents a short analysis of the problematic nature of customary international law within the context of international taxation and provides some views against and in favour of customary international law in that area. Subsequently, in section 3, we will evaluate fresh evidence generated by the above-mentioned forms of multilateral cooperation mentioned above. For this, we first expound on the minimum standard against tax treaty abuse and then analyse it in the light of the requirements for customary international law, identifying strong and weak arguments for the existence of customary law in international taxation. Section 4 will draw conclusions and recommendations for further research.

\section{Customary International Law and International Tax Law}

2.1

\section{Customary International Law}

2.1.1

Definition of Customary International Law

Customary international law is recognized as one of the sources of international law by art. $38(1)$ of the ICJ Statute. ${ }^{15}$ In general, a "rule of customary

12 See art. 38(1) ICJ Statute referring to the application by the ICJ of International custom, as evidence of a general practice accepted as law to international law disputes. The landmark cases for these two elements is the case of North Sea Continental Shelf (Federal Republic of Germany v. Denmark; Federal Republic of Germany v. the Netherlands), Judgement, I.C.J. Reports 1969 p. 3.

13 ILA Committee on the Formation of Customary (General) International Law, Statement of Principles Applicable to the Formation of General Customary International Law, Final Report of the Committee, London Conference 2000.

14 ILC, Identification of Customary International Law, Text of the Draft Conclusions Adopted by the by the International Law Commission 17th Session and submitted to the General Assembly as a part of the Commission's report covering the work of that session (A/73/10). The report and its Commentaries will appear in Yearbook of the International Law Commission, 2018, vol. II, Part Two.

15 For this section, use has been made of previous work: I. Mosquera Valderrama, "BEPS Principal Purpose Test and Customary International Law", 33 Leiden Journal of International Law (2020), pp. 745-766. doi:10.1017/Sog221565200oo278. 
international law is one which is created and sustained by the constant and uniform practice of States and other subjects of international law in or impinging upon their international legal relations, in circumstances which give rise to a legitimate expectation of similar conduct in the future".16

Customary international law requires two elements, which are the objective element (state practice) and the subjective element (accepted by law - opinio juris). These two elements will be briefly set out below.

\subsubsection{Objective Element: State Practice}

The state practice element exists when there is a sufficiently extensive and representative number of States participating in a practice in a consistent and uniform manner. ${ }^{17}$ These elements of state practice have been also addressed by the ICJ in several cases. For instance:

a) As regards the element of uniformity, the ICJ stated in the Asylum case and the Fisheries case $\mathrm{e}^{18}$ that uniformity of the state practice should be internal and collective. When analyzing these criteria, the ILA further explained that "internal uniformity means that each State whose behaviour is being considered should have acted in the same way on virtually all of the occasions on which is engaged in the practice in question. Collective uniformity means that different States must not have engaged in substantially different conduct, some doing one thing and some another". ${ }^{19}$

b) As regards the element of consistency, the ICJ stated in the Nicaragua case that "in order to deduce the existence of customary rules, the Court deems it sufficient that the conduct of States should in general be consistent with such a rule; and that instances of State conduct inconsistent

16 International Law Association (ILA), London Conference Statement of Principles Applicable to the Formation of General Customary International Law (200o) p. 8. See also D. M. Bodansky, "The Concept of Customary International Law", 16 Michigan Journal of International Law (1995).

17 ILA 200o, id., p. 8. And ILC, Identification of Customary International Law, Text of the Draft Conclusions Adopted by the by the International Law Commission 17th Session and submitted to the General Assembly as a part of the Commission's report covering the work of that session (A/73/10, para. 65) p. 3 .

18 Asylum (Colombia v. Peru), Judgement, I.C.J. Reports 1950 p. 266; Fisheries Case (United Kingdom v. Norway), Judgement, I.C.J. Reports 1951 p. 116.

19 International Law Association (ILA), London Conference Statement of Principles Applicable to the Formation of General Customary International Law (2000) p. 21. 
with a given rule should generally have been treated as breaches of that rule, not as indications of the recognition of a new rule."20

c) As regards the element that state practice must be widespread and representative, the ICJ held in the North Sea Continental Shelf case that, 'even without the passage of any considerable period of time, a very widespread and representative participation in the convention might suffice of itself, provided it included that of States whose interests were specifically affected'. ${ }^{21}$ This acceptance does not refer to a specific percentage of states, and it does not need to be universal. ${ }^{22}$

\subsubsection{Subjective Element: Accepted as Law (opinio juris)}

In respect of the subjective element, the ILA holds that "the subjective element means, for some, consent or will that something be a rule of customary law, and for others a belief that it is a rule - to put it simply. It is possible to achieve an elision or apparent reconciliation of these two approaches by using terms such as 'accepted' or 'recognized' as law. These words can connote a mere acknowledgment of an existing state of affairs (a declaratory viewpoint), or they may bear a constitutive meaning - States are bound by the rule because they choose to acknowledge". ${ }^{23}$ And according to the ILC, the subjective element requires that "the relevant practice must be undertaken with a sense of legal right or obligation, that is, it must be accompanied by a conviction that it is permitted, required or prohibited by customary international law". 24

20 Military and Paramilitary Activities (Nicaragua $v$ United States of America), Judgment, I.C.J. Reports 1986, p. 98.

21 North Sea Continental Shelf (Federal Republic of Germany v. Denmark; Federal Republic of Germanyv. the Netherlands), Judgement, I.C.J. Reports 1969, par. 73.

22 International Law Association (ILA), London Conference Statement of Principles Applicable to the Formation of General Customary International Law (2000) p. 25, refers to the North Sea Continental Shelf Cases and states that "given the inherently informal nature of customary law, it is not to be expected, neither is it, the case, that a precise number of percentage of States is required. Much will depend on circumstances, and, in particular, on the degree of representativeness of the practice".

23 ILA 200o, id., p. 30 and footnote 77 , stating that 'accepted as law is the expression used in Article $38(1)$ (b) of the Statute of the ICJ'.

24 ILC, Identification of Customary International Law, Text of the Draft Conclusions Adopted by the by the International Law Commission 17th Session and submitted to the General Assembly as a part of the Commission's report covering the work of that session $(A / 73 / 10)$ p. 18. 


\subsection{International Tax Taw as Customary International Law}

In the following sections, we will focus on the question whether customary international law can be discerned in the distributive rules of international tax law. ${ }^{25}$ We will not focus on the use of customary international law external to international tax law. Nevertheless, that is not to say that international tax law takes no account of the customary nature of such external rules of public international law.

For instance, there is ample evidence that the rules of interpretation of the Vienna Convention on the Law of Treaties (VCLT), designated as customary, ${ }^{26}$ are upheld as such in international tax practice and tax courts. ${ }^{27}$ For instance, the Dutch Supreme Court recently ruled that the interpretative rules of the VCLT are of a customary nature and therefore apply to tax treaties concluded before the VCLT came into force. ${ }^{28}$ As to the Draft Articles of State Responsibility, however: there is little evidence that these rules are invoked by tax courts in relation to bilateral tax treaty obligations, ${ }^{29}$ perhaps because the breach of a tax treaty is easily discovered (taxpayers will complain about double taxation), easily remedied (the reciprocal nature of tax treaties allows states to decline tax treaty benefits to residents of the defecting state) and scares off investors. ${ }^{30}$

25 Since 2018, at the International Law Association, a new study group in International Tax Law has been created. This Group has a mandate from 2018 to 2020 to undertake a preliminary investigation into human rights challenges in times of global tax transparency. The complete report will be published by the end of 2020. A short version of the report has been submitted to the ILA 79th Biennial Conference, Kyoto 2020. More information on the study group at https://www.ila-hq.org/index.php/study-groups?study-groupsID=8o. Accessed on 20 December 2020.

26 ICJ, LaGrand (Germany v. United States of America), Judgement, I.J.C. Reports 2001 p. 466.

27 See on this the 1993 country reports of the yearly assembly of the International Fiscal Association: K. Vogel and R.G. Prokisch, "General Report", in IFA (ed.), Interpretation of Double Taxation Conventions (IFA Cahiers vol. 78a 1993). Moreover, the customary status of the VCLT is readily accepted in international tax literature, see e.g. F. A. Engelen, Interpretation of Tax Treaties under International Law: A Study of Articles 31, 32 and 33 of the Vienna Convention on the Law of Treaties and their Application to Tax Treaties (2004).

28 Hoge Raad 19-01-2018, ECLI:NL:HR:2018:47, BNB 2018/68. Freely translated, at par. 2.3.2: 'the Vienna Convention was, at the time the Dutch-Singaporese Tax Treaty was concluded, not in force. Yet, the in the rules of interpretation of the Vienna Convention on the Law of Treaties codify international custom, implicating that these rules apply to the present case'.

29 See some remarks about tax cases unrelated to bilateral tax treaties H. Pijl, "State Responsibility in Taxation Matters", 6o Bulletin for International Taxation (2006) p. 38.

30 D. Ring, "International Tax Relations: Theory and Implications", 6o Tax Law Review (2007) p. 133 . 


\subsubsection{In Favour}

One of the first tax scholars addressing customary international law was Avi-Yonah. In 2004 and 2007, he raised the question whether customary international tax law exists. ${ }^{31}$ He questioned whether, in light of widely followed international tax practices (e.g. the use of the arm's length standard and similar methods to prevent double taxation) and considering the extensive and worldwide use of more than 2000 bilateral tax treaties based on the UN or OECD model tax treaties, customary international law may be identified in the area of international tax law. ${ }^{32}$

For the definition of customary international law, Avi-Yonah referred to the US Restatement (Third) of Foreign Relations Law (1987), generally encompassing the understanding of customary law laid out in section 2.1. ${ }^{33}$ He noted that: 'the hard question is whether countries not only follow a rule but do so out of a sense of legal obligation (opinio juris)'. ${ }^{34}$ With some examples, Avi-Yonah argued $^{35}$ that 'an international tax regime does exist and that it rises to the level of customary international law' ${ }^{36}$ He concluded that, as a consequence,

31 R. S. Avi-Yonah, "International Tax as International Law", 57 Tax Law Review (2004); R. S. Avi-Yonah, International Tax as International Law: an Analysis of the International Tax Regime (2007) p. 5. Another author who claims that international custom in international tax law exists is S. Gadžo, "The Principle of 'Nexus' or 'Genuine Link' as a Keystone of International Income Tax Law: A Reappraisal” 46 Intertax (2008). For him, it comes in the form of the "nexus principle", i.e. the qualifying connection between a state's territory and income.

32 Generally speaking, the OECD-G2o is reluctant to deal with redefining the allocation of taxing rights between those states. Other developments, in particular the 2019 OECD consultation on taxation of digital economy, show the same difficulty: https://www .oecd.org/tax/beps/public-consultation-document-addressing-the-tax-challenges-of-the -digitalisation-of-the-economy.pdf.

33 R. S. Avi-Yonah, "International Tax as International Law", 57 Tax Law Review (2004) p. 484, note 2.

34 R. S. Avi-Yonah, "International Tax as International Law", 57 Tax Law Review (2004) p. 498. E. Gil García, "The Single Tax Principle: Fiction or Reality in a Non-Comprehensive International Tax Regime" 11 World Tax Journal (2019).

35 In particular, he provided four widely used elements of international tax law to showcase his argument: (I.) the rules governing the jurisdiction to tax (i.e. source and residence); (II.) the non-discrimination standard, (III.) the arm's length standard and (IV.) the use of the exemption and credit methods to eliminate double taxation. R. S. Avi-Yonah, "International Tax as International Law", 57 Tax Law Review (2004) p. 496-500; R. S. Avi-Yonah, International Tax as International Law: an Analysis of the International Tax Regime (2007) pp. 5-7.

36 R. S. Avi-Yonah, International Tax as International Law: an Analysis of the International Tax Regime (2007) p. 5 . 
'in the United States, in the absence of treaties or legislation, resort can be made to customary international law'. 37

More recently (2019), Avi-Yonah reinvigorated his argument by again referring to traditional elements of international tax law, e.g. to the use of the permanent establishment threshold, the arm's length standard and the standard against discrimination, and the widely accepted way to allocate jurisdiction to tax by basing taxing claims on either the principle of residence or source, suggesting that 'CIL exists in some cases of tax law'. ${ }^{38}$

Even though customary international tax law's practical relevance may be limited in the US due to Congress' ability to override treaties, ${ }^{39}$ he points at some evidence where taxpayers, unlimited by explicit federal legislation, could have invoked customary international tax law within federal (US) courts. ${ }^{40}$ And outside the US, where international law is superior to domestic law (as is the case in the Netherlands), Avi-Yonah holds that taxpayers may invoke customary international law either in international courts or tribunals. ${ }^{41}$

Particularly interesting in this regard is Avi-Yonah's reference to the arbitration between Vodafone and the Government of India. In this case, Vodafone invoked customary international tax law to argue that India had no nexus to tax an indirect transfer of shares that took place outside of India. ${ }^{42}$ In the arbitration proceedings, 'Vodafone has argued that CIL governs the case and that under CIL there was no tax nexus in India, and that the retroactive tax amounted to an expropriation. Since the case is in an international arbitration

37 Reuven Avi-Yonah (2007), id, p. 501.

38 R. Avi-Yonah, "Does Customary International Tax Law Exist?", U of Michigan Law \& Econ Research Paper No. 19-005; U of Michigan Public Law Research Paper No. 640 (2019).

39 Avi-Yonah points out that in the United States, customary international law as well as treaties can be overridden by Congress through unilateral legislation, and perhaps even by Treasury through administrative action. See id., at sec. 6 .

In particular, Avi-Yonah points at the Piedras Negras case, relating to the physical presence requirement: Piedras Negras Broadcasting Co. v. Commissioner, (1941) 43 BTA 297, 127 F.2d 260 ( 5 th Cir.) 1942.

41 Id., at sec. 6.

42 The Vodafone case, Vodafone International Holdings BV. v. Union of India [2012] 341 ITR 1, dealt with the indirect transfer of shares by Vodafone that took place outside of India and, absent any legislation to the contrary, was not subject to taxation in India. However, the government of India decided retroactively and unilaterally to tax this indirect transfer of shares to an amount of USD 2.1 billion. The case has received attention by tax scholars, see for instance S. Vasudevan and M. Nagappan, "Indirect Transfer Taxation in India: From Vodafone to Cairn", 45 Intertax (2017); K. Susarla and R. Ravisankar, "Beyond Vodafone The Ripple Effect", 22 Asia-Pacific Tax Bulletin (2016); G. Loomer, "The Vodafone Essar Dispute: Inadequate Tax Principles Create Difficult Choices for India" 21 National Law School of India Review (2009). 
tribunal, CIL could decide the outcome despite the contrary explicit Indian legislation: 43

\subsubsection{Against}

Avi-Yonah's point, that there are some elements that make the international tax regime arise to the level of customary international law, has, so far, not stuck with others. ${ }^{44}$ Perhaps this is because his illustrations are generally US-centered, whereas the analysis of customary international law requires the worldwide analysis of two elements: objective (uniform, widespread, consistent and representative state practice) and subjective (opinio juris). ${ }^{45}$

For instance, Avi-Yonah illustrated the rules on the jurisdiction to tax by referring to the spread of controlled foreign company (CFC) legislation that allows countries to tax resident shareholders on the (deemed) income of foreign subsidiaries, avoiding directly taxing non-residents on their foreign source income. But traditionally, this is a typical US-type of tax rule; before 2013, CFC rules did not meet the element of state practice since the number of countries introducing $\mathrm{CFC}$ rules was not extensive nor representative. From the time of adoption of the CFC rules (1963) until the time that the BEPS Action 3 (concerning CFC rules) was published (2015), only 30 countries of the 193 countries around the world have adopted CFC legislation. ${ }^{46}$

43 R. Avi-Yonah, "Does Customary International Tax Law Exist?", U of Michigan Law \& Econ Research Paper No. 19-005; U of Michigan Public Law Research Paper No. 640 (2019).

44 Some of the views are discussed here. Others are: B.D. Lepard, "Is the United States Obligated to Drive on the Right: A Multidisciplinary Inquiry into the Normative Authority of Contemporary International Law Using the Arm's Length Standard as a Case Study", 10 Duke Journal of Comparative \& International Law (1999); M. Nieminen, "Dual Role of the OECD Commentaries - Part 1", 43 Intertax (2015) p. 639; the comparative law research by: Vega García, El Soft Law en la Fiscalidad Internacional (Tesis Doctoral, Universitat Pompeu Fabra Barcelona 2014), p. 549, who includes Latin American Countries like Ecuador, Mexico and Brazil in his analysis (p. 549); the position of some commentators of the GREIT 1oth annual conference: see: L. Allevi \& C. Celesti, "1oth GREIT Annual Conference on EU BEPS; Fiscal Transparency, Protection of Taxpayer Rights and State Aid and 7th GREIT Summer Course on Tax Evasion, Tax Avoidance \& Aggressive Tax Planning", 44 Intertax (2016), C. West, "References to the oEcD Commentaries in Tax Treaties: A Steady March from 'Soft' Law to 'Hard' Law?” 9 World Tax Journal (2017).

45 Avi-Yonah does not refer to consistency and focused mainly on state practice rather than opinion juris.

46 OECD, "Designing Effective Controlled Foreign Company Rules, Action 3-2015 Final Report", OECD/G2o Base Erosion and Profit Shifting Project, (2015). 
It is only after the recent adoption (and multilateral implementation of) the BEPS Project that countries are encouraged to introduce CFC legislation. ${ }^{47}$ Moreover, as regards the arm's length standard, Avi-Yonah's referred to the OECD's acceptance and assimilation of US practice as regards the application of the arm's length standard in its soft-law materials (i.e. the OECD/Un Model Treaties and their commentaries, and the Transfer Pricing Guidelines) as an illustration for these rules to become customary international tax law. But even though these rules have become part of the OECD's interpretative materials, it is an exaggeration to say that they thus have become widely used by countries around the world. 48

A stronger explanation that customary international tax law has been rejected, concerns the nature of international tax law. Traditionally, international tax law consists of bilateral agreements in which states reciprocally barter for economic gains under the common goal of preventing double taxation. These gains can be related to two conflicting interests. The type of gains states look for when concluding a tax treaty, depends on the nature of the bilateral economic relationship. A state can, vis-à-vis another state, be a capital importer (of capital, labour, etc.) and hence favour taxation at source. States with such an interest want to seek higher source taxes on e.g. dividends, to be able to tax money flows.

Alternatively, net export states want to protect their resident investors' interest, and seek to lower taxation at source in order to prevent tax treatment to deter cross border economic activity. To achieve economic gains, states have used bilateral tax treaties to coordinate on the prevention of double taxation. As flows (of capital, investment, etc.) are roughly comparable between developed states, the net revenue effect to the states of concluding a tax treaty should roughly be the same. ${ }^{49}$

In light of these goals, the majority of bilateral tax treaties are best seen as coordination devices, somewhat loosely used the OECD and UN Model Tax Treaties. They include concepts such as the arm's length concept, the permanent establishment concept, the non-discrimination standard and methods to eliminate double taxation, as coordination rules, of which it is expected that

47 As BEPS Action 3 is not regarded as a minimum standard for countries of the BEPS Inclusive Framework, the number of countries expected to adopt CFC legislation may be less than the 129 countries participating in the Framework.

48 For instance, Brazil has adopted the comparable margins method which is different to the arm's length method, clearly not following OECD standards.

49 See D. M. Ring, "International Tax Relations: Theory and Implications", 6o Tax Law Review (2007) pp. 133-134. 
they generate acceptable outcomes (in terms of economic gains, like FDI or tax revenue, etc.) for all those involved. ${ }^{50}$

The wide use of such "core" international tax concepts, set out in model tax conventions such as the OECD and UN Model Tax Conventions, may then also be explained. There is a clear benefit of using pre-determined coordination rules, as using them imports the full legal context of such rules into the ambit of tax treaties. This, in other words, prevents states to enter into expensive and long distributive discussions that they have already entered into before. ${ }^{51}$ States have hence not decided to use "core" international tax law concepts, such as the arm's length standard and the permanent establishment standard, in their treaties because they believe them to be law (opinio juris), but because it provides them with a cheap option to coordinate on the common goal of preventing double taxation. As Rosenbloom explains in this respect, the use of tax treaties by countries to prevent double taxation is optional and therefore the existence of an international tax regime emerging from customary international law must be denied. ${ }^{52}$

The argument that (some of) the coordination rules set out the OECD/UN Model Tax Treaty are customary international law, i.e., applicable even in the absence of a bilateral tax treaty, is therefore mistaken: it overlooks the fact that states enter into and comply with tax treaties out of self-interest only. To maximize economic gains, and that to prevent expensive lengthy discussions each time they conclude a bilateral tax treaty, states make use of internationally agreed upon standards (that are hence not part of customary international law). ${ }^{53}$

And then there is another important argument. It relates to the identification of customary law in an area that is greatly influenced by diverging international tax policies of different countries. Due to the "complex arrangements for mutual deference under bilateral tax treaties, it is difficult to imagine these

50 As regards treaties between developed and developing countries, a somewhat different reasoning applies, but it may still be assumed that developing countries enter into bilateral tax treaties with developing countries out of self-interest (i.e. tax treaties are helpful to attract foreign investment). They then may have little choice but to accept international tax standards used by developed countries. See Ring, id., pp. 134-139.

$5^{1} \quad$ pp. 59-93.

52 See D. Rosenbloom, "International Tax Arbitrage and the International Tax System: The David R. Tillinghast Lecture", 53 Tax Law Review (2000).

53 See also in this regard D. M. Ring, "International Tax Relations: Theory and Implications", 6o Tax Law Review (2007), who in addition argues that countries are able to self-enforce bilateral tax treaties. As defections will generally be transparent (i.e., it comes in the form of taxpayers facing double taxation), investors to refrain from investing. See p. 133 . 
varied and complex arrangements arising from and becoming empirically identifiable under a CIL regime. There are so many details and contingencies, conditions, and exceptions that it would be difficult to identify the custom".54 In such a complex area, it follows from the work of Hongler, it is much more practical to resort to the use of tax treaties. And indeed, the use of customary international law in international taxation has certain limits, as the pedigree of tax treaties, and the likelihood of compliance under tax treaties, is better than under customary international law. Moreover, the legality principle is important for tax purposes. ${ }^{55}$ For that reason, Hongler concludes: "customary law is not an efficient source of law making for the international tax regime. Various reasons have proven that the development of customary international tax law might be limited due to its complexity, technicality, and the fact that the legality principle is often crucial for tax purposes.". 56

Finally, the matter of customary international law has to be considered in relation to the position of developing countries. One of the authors of this article has argued elsewhere that in the shift from bilateral to multilateral initiatives there is also controversy "in respect of allocation of taxing rights between source country and residence country, since the different interests from developing countries (more source taxation) vs. developed countries (more residence taxation) can make it difficult to achieve rules that are accepted by all countries. Two examples illustrate this. The first is the OECD-G2O reluctance to deal with allocation of taxing rights in the BEPS Project. The second is the 2019 OECD consultation on the taxation of the digital economy that presents policy options which represent different countries' approach, (i) from the OECD-G2O countries, (ii) from the United States, and (iii) from the EU, and G24 (mainly developing) countries. Due to the lack of a consensus for one of the three policy options, the OECD Secretariat presented its own 'Unified Approach Proposal' which is being discussed at the time of writing". ${ }^{57}$

54 See J. Trachtman, "The Growing Obsolescence of Customary International Law", in C. Bradley (ed.), Custom's Future: International Law in a Changing World (2016).

55 P. Hongler, Justice in International Tax Law: A Normative Review of the International Tax Regime (2019), sections 4.3.2.6-4.3.2.8.

56 P. Hongler, Justice in International Tax Law: A Normative Review of the International Tax Regime (2019), section 4.3.2.7.

57 I.J. Mosquera Valderrama, "BEPS Principal Purpose Test and Customary International Law”, 33 Leiden Journal of International Law (2020), p. 755. 


\section{Evidence of Customary International Law in the Light of Recent Developments in International Taxation}

From the above follows that the acceptance of customary international law is problematic, particularly when considering that 'traditional' international tax law is about dealing with coordination problems. ${ }^{58}$ In short, there is a strong argument to say that international tax law is made and complied with out of self-interest, not because states believe that they must adhere to some form of overarching customary norm.

However, the case for customary international law is more compelling when a norm has been formulated to solve some collective action problem, i.e., where the common interest is at stake. Examples are prisoners' dilemmas, where individualistic, uncoordinated behaviour may lead to suboptimal outcomes for all. ${ }^{59}$ In such cases, the situation "calls" for a strong and authoritative norm, particularly when existing norms are absent or defected from, making the case for customary international law more appealing. This "call" exerted by prisoners' dilemmas, is what Ullman Margalit calls the need for a 'stabilizing device', that would 'eliminate the temptation to deviate from what is obviously the "good" action'. ${ }^{60}$ Consequently, Ullman Margalit argues, prisoner's dilemmas generate contexts which are prone to generate norms. ${ }^{61}$

It is therefore not surprising that it is appealing for tax scholars to look for customary law norms in prisoners' dilemma-rich contexts. And the case is, that most of international tax law's current major policy challenges involves prisoners' dilemma's, namely tackling aggressive tax planning. Indeed, as regards rules impacting bilateral tax treaties, the most significant development is the almost general acceptance of a general anti-abuse clause preventing the abuse of tax treaties, the so-called principal purpose test or PPT. The principal purpose test has been adopted by most of the countries (136 of the 137 jurisdictions) of the BEPS Inclusive Framework. Therefore, it is safe to argue that this standard will be widely applied by G2O, OECD, and non-OECD, non-G2O countries committed to the BEPS Inclusive Framework and/or signatories of the MLI. ${ }^{62}$ Consequently, it may be said that the principal purpose test

$5^{8}$ See also B.D. Lepard, "Is the United States Obligated to Drive on the Right: A Multidisciplinary Inquiry into the Normative Authority of Contemporary International Law Using the Arm's Length Standard as a Case Study", 10 Duke Journal of Comparative \& International Law (1999), p. 112.

59 Id., p. 112.

6o E. Ullmann-Margalit, The Emergence of Norms, (Paperback Edn, 2015), pp. 29-30.

61 Id, p. 22.

62 At the time of writing, the United States is the only country of the BEPS Inclusive Framework that has not adopted the principal purpose test. 
is regarded by developed and developing countries alike as one of the most important and desirable solutions to tackle treaty abuse and treaty shopping by multinationals.

Hence, as we will show below, the appeal of customary international tax law in the era of BEPS and combating aggressive tax planning, is not misplaced. Instead, the fact that more than 130 jurisdictions participate in the BEPS Inclusive Framework, working on norms to tackle prisoner dilemma type of problems (i.e. aggressive tax planning), may suggest that the formation of customary international tax law may occur. To provide more flesh on these bones, we set out the background and general characteristics of the principal purpose test in section 3.1. We will then look for evidence in sections 3.2 and $3.3 .{ }^{63}$

\subsection{The Principal Purpose Test, the BEPS Project and the Multilateral Instrument}

Action 6 of the BEPS Project ('preventing the granting of treaty benefits in inappropriate circumstances'), ${ }^{64}$ introduced a minimum standard to counter treaty abuse. ${ }^{65}$ The minimum standard offered participating countries some degree of flexibility. Countries could adopt in their tax treaties one of the following rules to counter tax treaty abuse: (i) the principal purpose test; (ii) the principal purpose test with either a simplified or detailed limitation on benefits (LOB) provision (i.e., a rule allowing treaty benefits only when objective criteria are met, which are described in detail), and (iii) a detailed Lов with anti-abuse measures to counteract conduit financing. ${ }^{66}$

63 For sections 3.2 to 3.4. use has been made of previous work by I. Mosquera Valderrama, "BEPS Principal Purpose Test and Customary International Law", 33 Leiden Journal of International Law (2020), pp. 745-766. doi:10.1017/Sog2215652000o278.

64 According to the OECD, "Treaty shopping' generally refers to arrangements through which a person who is not a resident of one of the two States that concluded a tax treaty may attempt to obtain benefits that the treaty grants to residents of these States. These strategies are often implemented by establishing companies in States with desirable tax treaties that are often qualified as 'letterboxes' 'shell companies' or 'conduits' because these companies exist on paper but have no or hardly any substance in reality". See http://www.oecd.org/tax/beps/beps-frequentlyaskedquestions.htm\#Action6. Accessed on 20 December 2020.

65 Treaty abuse is described by the OECD as: "a number of arrangements through which a person who is not resident of a Contracting State may attempt to obtain benefits that a tax treaty grants to a resident of that State". See OECD, "Preventing the Granting of Treaty Benefits in Inappropriate Circumstances, Action 6-2015 Final Report", OECD/G2o Base Erosion and Profit Shifting Project (2015), par. 17.

66 Also, it introduced a new preamble to tax treaties. The preamble states: "Intending to conclude a Convention for the elimination of double taxation with respect to taxes on income and on capital without creating opportunities for non-taxation or reduced taxation through tax evasion or avoidance (including treaty shopping arrangements aimed 
The minimum standard does not only allow countries flexibility in terms of what type of rule may be used; it also leaves it to the discretion of states of how it is implemented. To facilitate implementing the outcomes of the BEPS Project, participating countries may make use of the (legally binding) Multilateral Instrument, which introduce the minimum standard in bilateral tax treaties "in one fell swoop", i.e., without necessitating lengthy bilateral negotiations of bilateral tax treaties.

But the Multilateral Instrument is not compulsory; if countries prefer, they may also implement the minimum standard by means of bilateral negotiations. Performance is measured by means of peer review: 67 in the 2018 peer review report of Action 6 of a total of 116 countries, $5^{6}$ countries expressed their choice for the principal purpose test; ${ }^{68}{ }_{27}$ countries decided to apply the principal purpose test with a simplified or detailed цов. ${ }^{69} 3^{2}$ countries did not mention their choice, but it is expected that these countries will apply the principal purpose test. ${ }^{70}$ Hence, the commitment to the minimum standard

at obtaining reliefs provided in this Convention for the indirect benefit of residents of third states)".

67 The terms of reference for peer review of Action 6 refers to "a mechanism (such as a treaty rule that might take the form of a PPT rule restricted to conduit arrangements, or domestic anti-abuse rules or judicial doctrines that would achieve a similar result) that would deal with conduit arrangements not already dealt with in tax treaties", see OECD, "Prevention of Treaty Abuse - Peer Review Report on Treaty Shopping: Inclusive Framework on BEPS: Action 6", OECD/G2o Base Erosion and Profit Shifting Project (2019), https://doi.org/10.1787/9789264312388-en p. 16.

68 From the peer review of 116 countries, 56 countries have explicitly mentioned the application of PPT : Andorra, Australia, Austria, Barbados, Burkina Faso, Cameroon, Costa Rica, Cote d'Ivoire, Croatia, Curacao, Czech Republic, Egypt, Estonia, Finland, France, Gabon, Georgia, Guernsey, Hong Kong, Hungary, Ireland, Isle of Man, Israel, Italy, Jersey, Korea, Liechtenstein, Lithuania, Luxembourg, Malaysia, Malta, Monaco, the Netherlands, New Zeeland, Nigeria, Pakistan, Panama, Portugal, Qatar, Romania, San Marino, Saudi Arabia, Serbia, Singapore, Slovenia, South Africa, Spain, Sweden, Switzerland, Tunisia, Turkey, Ukraine, United Arab Emirates, the United Kingdom, Uruguay and Zambia.

69 From the peer review of 116,27 countries have explicitly mentioned the application of PPT combined with simplified or detailed цов: Argentina, Belgium, Brazil, Bulgaria, Canada, Chile, China, Colombia, Denmark, Germany, Greece, Iceland, India, Indonesia, Jamaica, Japan, Kazakhstan, Latvia, Mauritius, Mexico, Norway, Peru, Poland, Russia, Senegal, Seychelles, Slovak Republic.

70 Angola, Anguilla, Bahamas, Bahrain, Belize, Benin, Bermuda, Botswana, British Virgin Islands, Brunei, Cayman Islands, Congo, Djibouti, Haiti, Kenya, Liberia, Macau, Maldives, Mongolia, Montserrat, Oman, Papua New Guinea, Paraguay, Saint Kitts \& Nevis, Sierra Leone, Sri Lanka, Saint Lucia, Thailand, Trinidad \& Tobago, Turks \& Caicos Island, Vietnam. 
against treaty shopping constitutes a political obligation, which countries may meet and implement in varying ways.

If countries decide to use the Multilateral Instrument to swiftly implement the tax treaty related outcomes of the BEPS Project in their bilateral tax treaty relationships, it forms, however, hard law. ${ }^{71}$ And interestingly, the Multilateral Instrument shows some signs that, generally speaking, countries prefer the principal purpose test out of the three options to counter tax abuse spoken of above.

Making use of the Multilateral Instrument means agreeing to the principal purpose test by default. Countries may 'add' a цов to the default rule, ${ }^{72}$ yet the Multilateral Instrument only authorizes reservations on the principal purpose test when a participating country: (1) intends to meet the minimum standard (by choosing options (ii) or (iii)) in a bilateral tax treaty in another - mutually satisfactory - way, or (2) when a participating country's tax treaties already contain a principal purpose test. ${ }^{73}$ This allows the freedom that parties (e.g. Colombia) implement the principal purpose test as a 'default' interim measure. Other countries (e.g. Senegal) filed a reservation to the principal purpose test for tax treaties that already contained a main purpose test (similar in function but different in wording). ${ }^{74}$

\subsection{Elements of the Principal Purpose Test}

The principal purpose test states that "Notwithstanding the other provisions of this Convention, a benefit under this Convention shall not be granted in respect of an item of income or capital if it is reasonable to conclude, having regard to all relevant facts and circumstances, that obtaining that benefit was one of the principal purposes of any arrangement or transaction that resulted directly or indirectly in that benefit, unless it is established that granting that benefit in these circumstances would be in accordance with the object and purpose of the relevant provisions of this Convention".75

71 The MLI applies only to tax treaties designated by participating countries as "covered tax agreements". The MLI hence does not apply to agreements not "covered" by the MLI. See art. 2, paragraph $1(\mathrm{a})$, MLI.

72 Article 7, paragraph 4, MLI.

73 Article 7, paragraph 15, MLI and art. 7, paragraph 16 MLI.

74 See the positions of countries in respect of the MLI https://www.oecd.org/tax/treaties/ beps-mli-signatories-and-parties.pdf. Accessed on 20 December 2020.

75 OECD, "Preventing the Granting of Treaty Benefits in Inappropriate Circumstances, Action 6-2015. Final Report", OECD/G20 Base Erosion and Profit Shifting Project (2015), p. 55 . 
From the text of the principal purpose test, it follows that it has two elements i.e. subjective and objective. The subjective element requires that it must be reasonable to conclude, having regard to all relevant facts and circumstances, that obtaining the benefit (of a tax treaty) was one of the principal purposes of any arrangement or transaction that resulted directly or indirectly in that benefit. The tax administration bears the burden of proof in this regard. The objective element needs to be proven by the taxpayer, and requires that the taxpayer must establish that granting that benefit in these circumstances would be in accordance to the object and purpose of the relevant provisions of the tax treaty as to which it applies.

Therefore, the principal purpose test is by its own nature general, vague and imprecise $^{76}$ and consequently follows some of the main features highlighted by international law scholars when addressing international customary law. ${ }^{77}$ Its vagueness has in any case set many pens in motion, as its legally uncertain application brings challenges e.g. regarding the division of the burden of proof (subjective vs. objective element), its relationship with specific tax treaty abuse rules, ${ }^{78}$ its relation with EU law, ${ }^{79}$ and as to its interpretative flexibility, as it allows countries to exercise their international tax policy underneath the

76 See Section 3.1. above.

77 M. E. Villiger, Customary International Law and Treaties: A Manual on the Theory and Practice of the Interrelation of Sources (2nd ed. 1997) pp. 167-193.

78 Whether the principal purpose test functions as an "umbrella" abuse rule as regards other specific anti-abuse rules (i.e. of the MLI or outside it), is still an open question. Some of the main articles on the principal purpose test are: V. Chand, "The Principal Purpose Test and the Multilateral Convention: An In-depth Analysis", 46 Intertax (2018); D. Duff, "Tax Treaty Abuse and the Principal Purpose Test: Part I", 66 Canadian Tax Journal (2018) and D.Duff, "Tax Treaty Abuse and the Principal Purpose Test: Part II" 66 Canadian Tax Journal (2018); B. Kuźniacki, “The Principal Purpose Test (PPT) in BEPS Action 6 and the MLI", 10 World Tax Journal (2018); P. Piantavigna, "The Role of the Subjective Element in Tax Abuse and Aggressive Tax Planning" 1o World Tax Journal (2018); D. Weber, "The Reasonableness Test of the Principal Purpose Test Rule in OECD BEPS Action 6 (Tax Treaty Abuse) versus the EU Principle of Legal Certainty and the EU Abuse of Law Case Law", 1 Erasmus Law Review (2017) and S. van Weeghel, "A Deconstruction of the Principal Purpose Test", 11 World Tax Journal (2019).

79 The EU Anti-Tax Avoidance Directive, Council Directive (EU) 2016/1164, 12 July 2016, also includes a general anti-avoidance rule but applies to domestic law. See for some comments as to the relationship between the two different tests http://kluwertaxblog.com/. Accessed on 20 December 2020. 
broad ambit of the rule..$^{80}$ As we will discuss below, it is far from clear whether the standard will be interpreted and applied in a uniform manner. ${ }^{81}$

\subsection{The Principal Purpose Test as Customary International Law: Gathering the Evidence}

In light of the developments, the question may now be asked what evidence exists that would point in the direction of customary international law. We will discuss this by reference to the two requirements for customary international law: the objective and subjective element.

\subsubsection{Objective Element}

First and foremost, it can be safely argued that the signature (and ratification) of the Multilateral Instrument by countries will greatly affect tax treaty practice. The existence of the principal purpose test as "default" rule of the Multilateral Instrument and subsequent treaty practice generated by following this rule, may contribute to enhance the formation of the principal purpose test as a rule of customary law. ${ }^{82}$ Moreover, first evidence as to its broad application in international tax matters is slowly forming: from the 137 jurisdictions (at the time of writing) committed to the BEPS Inclusive Framework, 136 have committed to include the principal purpose test in their tax treaties either through bilateral negotiations or through signing the MLI. In addition, Cyprus, which is not participating in the BEPS Inclusive Framework, has chosen to adopt the principal purpose test by means of the MLI.

But there is more. The contents of the principal purpose test are to some extent based on a guiding anti-abuse principle ${ }^{83}$ first introduced in the OECD

8o As Eliffe notes: "there are many reasons why a harmonized basis of interpretation [of the PPT ] may not, in reality emerge". C. Eliffe, "The Meaning of the Principal Purpose Test: One Ring to Bind them All?" 11 World Tax Journal (2019), p. 47.

81 D. Duff, "Tax Treaty Abuse and the Principal Purpose Test: Part I", 66 Canadian Tax Journal (2018) and D. Duff, "Tax Treaty Abuse and the Principal Purpose Test: Part II" 66 Canadian Tax Journal (2018).

82 In International law, some authors have addressed the relationship between multilateral treaties and customary international law. See W. A. Thirlway, International Customary Law and Codification (1972), and R. B. Bilder et. al., "Disentangling Treaty and Customary International Law", 81 Proceedings of the Annual Meeting (American Society of International Law 1987).

83 D. G. Duff, "Tax Treaty Abuse and the Principal Purpose Test Part. II", 66 Canadian Tax Journal (2018) at p. $95^{2}$. 
Commentary (i.e. the official - and influential - Commentary to the OECD Model Tax Convention) in 2003 ${ }^{84}$ This guiding principle states that "the benefits of a double taxation convention should not be available where a main purpose for entering into certain transactions or arrangements was to secure a more favorable tax position and obtaining a more favorable treatment in these circumstances would be contrary to the object and purpose of the relevant provision".85 It has since - although not widely and not uniformly - influenced the interpretation of tax treaties when applying them to domestic anti-abuse rules. ${ }^{86}$

Indeed, as Van Weeghel shows, the principal purpose test did not fall out of thin air, but can be related to emerging ideas about abuse of tax treaties from 1977 onwards, leading to the Harmful Tax Competition project of 1998 and the more strongly worded changes regarding to tax treaty abuse of the OECD Commentary in 2003, and finally resulting in the rule now part of the BEPS Project and the Multilateral Instrument. ${ }^{87}$

It has thus already been of influence in tax treaty application. Indeed, outcomes of this process can for instance be found in cases such as the 2005 case in $A$ Holding $A p S^{88}$ where the Swiss Federal Court, by reference to the OECD Commentaries and academic writing, held that the doctrine of abuse of rights applied to double taxation conventions even in the absence of specific antiabuse provisions in the applicable bilateral tax treaty. This suggests that the introduction of the PPT follows a longer process of social acceptance (also

84 The OECD has developed a Model for Tax Treaties including also an oECD Commentary. This Model and Commentary are guidelines/recommendations used by countries to conclude and interpret bilateral tax treaties. On the "legal status" of the oEcD Commentary in international law see e.g. S. C. W. Douma and F. A. Engelen (eds.), The Legal Status of the OECD Commentaries (2008).

85 Paragraph 9.5. of the commentary on article 1 of the 2003 OECD Model Convention.

86 See e.g. Van Weeghel in the International Fiscal Association's General Report: "The branch reports establish that in many countries the application of domestic anti-abuse rules is consistent with tax treaty obligations". S. van Weeghel, "General Report", in Tax Treaties and Tax Avoidance: Application of Anti-Avoidance Provisions, (IFA Cahiers, Volume 95A, 2010).

87 S. van Weeghel, "A Deconstruction of the Principal Purposes Test", 11 World Tax Journal (2019) sec. 2.

88 A Holding A.p.S. v. Federal Tax Administration, (2005) 8 ITLR 536; 2A/239/2005. 
named acculturation by some $)^{89}$ of anti-abuse norms in international taxation, even if a tax treaty does not contain one. ${ }^{90}$

There is one important exception to the wide application of the principal purpose test. The United States has persistently deviated from the principal purpose test during the drafting of BEPS Action 6, and decided to apply its own rules, i.e. the detailed LOB and anti-conduit financing rules. Moreover, as the United States decided not to sign the MLI, its tax treaties concluded by the United States with other countries will not be covered by it. Therefore, it is expected that the negotiation of tax treaties with the US - if it will - will take place bilaterally. ${ }^{91}$

Since the United States did not embrace the principal purpose test, the question is whether: (1) this prevents customary international law from forming, as one important state has decided to follow a different path, and (2) if it does, whether the US can be regarded as persistent objector and if so, whether the result will be the fragmentation of customary international law, with all consequences for the principal purposes test's coherent interpretation. It is however important to keep in mind that the principal purpose test may also be residual customary international law - i.e. part of customary law unless parties have agreed to something different. ${ }^{92}$

\subsubsection{Subjective Element: Accepted as Law (opinio juris)}

The issue of customary international law's subjective element has in our view been more problematic for international tax law. As shown above in section 2.2.,

89 With acculturation, Goodman and Jinks refer to the process by means of which actors adopt the beliefs and behavioural patterns of the surrounding culture (i.e. by means of which actors conform to new rules as these are more and more socially accepted). R. Goodman and D. Jinks, "How to Influence States: Socialization and International Human Rights Law", 54 Duke Law Journal (2004).

9o See the Israeli Supreme Court case of Yanko-Weiss Holdings Ltd v. Holon Assessing Office, 10 ITLR 524, appeal No o0109o/o6, and the French Conseil d'Etat case in Ministre de l'Economie, des Finances et de l'Industrie v. Société Bank of Scotland, (2006) 9 ITLR 683; $\mathrm{N}^{\circ} 283314$, on whether a general anti-avoidance principle applies in interpreting tax treaties, even in the absence of a specific anti-abuse rule.

91 As stated in the peer review report of Action 6, "the United States expects to comply with the minimum standard through a detailed цов which is not available through the MLI. Therefore, the United States did not sign the MLI and will implement the minimum standard bilaterally". OECD, "Prevention of Treaty Abuse - Peer Review Report on Treaty Shopping: Inclusive Framework on BEPS: Action 6", OECD/G2o Base Erosion and Profit Shifting Project (2019) p.249.

92 Further research should be carried out regarding the role of the United States as a persistent objector and the use of the principal purpose test as a residual customary rule. 
the developments of international tax law have moved from coordinating on bilateral relationships, to solving a prisoners' dilemma in the form of tackling aggressive tax planning. Is, in the meantime, another underlying shift taking place, from "consequentialist" international tax law (i.e. applied "out of selfinterests") to "appropriate" international tax law (i.e., "norm or 'belief'-based, applying regardless of individual self-interests")? ${ }^{93}$ This would, in our view, provide strong evidence in favour of the formation of customary international tax law.

In this respect, García Antón has uncovered the same dichotomy as regards current multilateral initiatives when he says that the Multilateral Instrument presents on one side a multilateral layer representing a high degree of consensus in the long march towards customary international law, allowing the enforcement of normative principles such as the single tax principle, and on the other side, a bilateral layer introducing a high degree of flexibility. ${ }^{94}$ According to García Antón, the BEPS four minimum standards, when put in context with the OECD's Inclusive Framework and under the umbrella of the single tax principle, constitute an embryonic stage in the evolution of customary international law in anti-avoidance. ${ }^{95}$

What García Antón, in fact, suggests, is that the potential shift identified above exists. On the one hand, the BEPS Project must be matched with enough flexibility to accommodate countries' diverging international tax policies (i.e., use international tax law out of self-interest). As the OECD put it in the BEPS Action 6 Final Report: "Countries have therefore agreed to include anti-abuse provisions in their tax treaties, including a minimum standard to counter treaty shopping. They also agree that some flexibility in the implementation of the minimum standard is required as these provisions need to be adapted to each country's specificities and to the circumstances of the negotiation of bilateral conventions". ${ }^{96}$

93 This distinction between interest and idea driven norms is borrowed from J. G. March and J. P. Olsen's "the logic of appropriateness" and the "logic of consequences". J. G. March and J. P. Olsen, "The Institutional Dynamics of International Political Orders", 52 International Organization (1998).

94 R. García Anton, Multilateral Dynamics in Bilateral Settings: Back to Realpolitik, [2019] British Tax Review 2019, par. 4.1 and 5. For Garcia Anton, "The examples in the field of Public International Law, namely in the Law of the Sea, show the precise interaction between a multilateral treaty and customary international law, either by codifying it or by introducing norms in symbolical aspiration to become it".

95 Id., par. 4.1 and 5.

96 OECD, "Preventing the Granting of Treaty Benefits in Inappropriate Circumstances, Action 6-2015. Final Report", OECD/G2o Base Erosion and Profit Shifting Project (2015), http://dx.doi.org/10.1787/9789264241695-en p. 9 . 
Indeed, for some states, it will remain important to have substantive individual influence on international tax rules, e.g. to attract foreign investment. But on the other hand, action on the international level must necessarily be accompanied by a level playing field, required to solve the prisoners' dilemma of tackling aggressive tax planning. The only way to solve double non- or under-taxation is when anti-abuse rules are globally enforced. ${ }^{97}$ The Action 6 report recommends a "minimum level of protection that should be implemented". 98 So, the use of "minimum standards" provide clear signs of a level playing field.

It is, however, in our view, not (merely) self-interests that drive the formation and process of this level playing field, i.e., of coherently adopting rules against aggressive tax planning. The 2008 crisis created a new framework where the OECD following the political mandate of the G2o decided to introduce global standards to be followed not only by OECD or G2o countries but also by developing countries. ${ }^{99}$ Publics in western countries call for increased political attention to cracking down on tax avoidance, as the public outrage caused by e.g. the Lux Leaks as well as the Panama and Paradise Papers show. ${ }^{100}$ This is evidenced by language used by countries in the BEPS Project and the MLI. In example, the oECD holds that the BEPs Project was developed "because there was an urgent need to restore the trust of ordinary people in the fairness of their tax systems",101 as "governments are harmed (...) individual taxpayers are harmed (...) businesses are harmed."102 Moreover, the preamble of the MLI states that the Parties to it recognize that "governments lose substantial corporate tax revenue because of aggressive international tax planning that has the effect of artificially shifting profits to locations where they are subject to nontaxation or reduced taxation" and are "conscious of the need to ensure swift,

97 See: R. García Anton, "Multilateral Dynamics in Bilateral Settings: Back to Realpolitik", [2019] British Tax Review (2019), par. 5.

98 OECD, "Preventing the Granting of Treaty Benefits in Inappropriate Circumstances, Action 6-2015. Final Report", OECD/G20 Base Erosion and Profit Shifting Project (2015), http://dx.doi.org/10.1787/9789264241695-en p. 14 .

99 See the OECD's website: http://www.oecd.org/tax/transparency/. Accessed on 20 December 2020 .

100 See the International Consortium of Investigative Journalists website: http://www.icij .org/project/luxembourg-leaks and https://www.icij.org/investigations/panama-papers/. Accessed on 20 December 2020.

101 OECD, "Explanatory Statement to the Multilateral Convention to Implement Tax Treaty Related Measures to Prevent Base Erosion and Profit Shifting", OECD/G2O BEPS Project (2016), p. 4.

102 OECD, "Action Plan on Base Erosion and Profit Shifting" (2013), http://www.oecd.org/ctp/ BEPSActionPlan.pdf, p. 8. 
co-ordinated and consistent implementation of treaty-related BEPS measures in a multilateral context". ${ }^{103}$ And finally, it is evidenced by the peer review process of the BEPS Action Plan, by means of which a level playing field has come into function: I will restrict my rules if you do so too.

One important element of the peer review process related to BEPS Action 6 is that "a jurisdiction is required to implement the minimum standard when requested to do so by another member of the Inclusive Framework,", 104 even when that jurisdiction did not sign the Multilateral Instrument. Consequently, most of the peer reviewed jurisdictions have introduced or expressed their intention to introduce the principal purpose test with a preamble in their treaties, and in some cases supplemented it with a simplified цов or a detailed LOB, even if that ran contrary to clearly expressed interests.

Nevertheless, we recognize that disentangling the above-mentioned dichotomy between "consequentialist" and "appropriate" international tax law is hard: it is unclear whether states comply with the BEPS Action 6 Standard (through the peer review process or otherwise) due to political pressure placed on them by others, or whether states believe that introducing an anti-abuse rule such as the principal purpose test is "the right thing to do". But it does show that changes to international tax rules, in the form of hard law, take place, even against the clear self-interest of some states. More research 'on the ground' as regards the implementation of the BEPS Action Plan in different countries is necessary to uncover this interesting tension. ${ }^{105}$

\section{$4 \quad$ Conclusions and Recommendations for Further Research}

The main question addressed in this article is what evidence exists for (the formation of) rules of customary international law in the international tax law? Traditional discussions on the topic have always focused on rules addressing the coordination problem of solving double taxation. Customary international law was not accepted within this framework of coordination rules, as opinio juris was considered absent.

\footnotetext{
103 MLI, Preamble.

104 OECD, "Prevention of Treaty Abuse - Peer Review Report on Treaty Shopping: Inclusive Framework on BEPS: Action 6", OECD/G2o Base Erosion and Profit Shifting Project (2019) https://doi.org/10.1787/9789264312388-en, p. 16.

105 This research is currently being carried out by the European Research Council funded project GLOBтAXGOV (Global Tax Governance). This project is currently researching the implementation of the BEPS 4 Minimum Standards (BEPS Actions 5, 6, 13 and 14) in 12 countries. Information on the project: https:/globtaxgov.weblog.leidenuniv.nl/about/.
} 
But current multilateral initiatives in international tax law, of which most importantly the BEPS Project, its related Multilateral Instrument and Inclusive Framework, have radically changed the way and degree of participation by means of which international tax law is formed. The widely accepted rule against treaty shopping and treaty abuse, i.e. the principal purpose test, is the most prominent example in this regard.

As international tax law norms are slowly reformed and driven not only by states' self-interests, but by the idea that tackling aggressive tax planning is the right thing to do, customary norms may form. Questioning the existence of customary international tax law in the era of BEPS and tackling aggressive tax planning, and beyond, is therefore not misplaced.

\section{Acknowledgements}

This article is the result of the ERC research in the framework of the GlobTAXgov Project (2018-2023). This Project investigates international tax law making, including the adoption of OECD and EU standards by twelve countries. See Globtaxgov, https://globtaxgov.weblog.leidenuniv.nl/. The GLOBTAXgov Project has received funding from the European Research Council (ERC) under the European Union's Seven Framework Programme (FP/2007-2013) (ERC Grant agreement n. 758671). 